\title{
Enhanced siderophore production and mouse kidney pathogenicity in Escherichia coli grown in urine
}

\author{
S. SHARMA, K. HARJAI and R. MITTAL
}

Department of Microbiology, Panjab University, Chandigarh-160014, India

\begin{abstract}
Summary. Fifteen siderophore producing urinary isolates of Escherichia coli were compared for aerobactin and enterochelin production in trypticase soy broth and pooled normal human urine. Significant increase in siderophore production (both phenolate and hydroxamate) was observed when organisms were grown in urine. Mouse kidney pathogenic potential of the strains grown in urine was compared with that of bacteria grown in trypticase soy broth in an ascending model of pyelonephritis in female Swiss Webster mice. Organisms grown in urine and instilled into a mouse bladder demonstrated markedly enhanced renal pathogenicity $(p<0 \cdot 01)$. Further information about the influence of urinary constituents on siderophore production could help in understanding the pathogenesis of pyelonephritis.
\end{abstract}

\section{Introduction}

With few exceptions, iron is essential for growth of bacteria. ${ }^{1-3}$ In spite of the abundance of iron in animal tissues, the amount available to the bacteria is extremely small. ${ }^{4}$ In the body, most of the iron is intracellular and extracellular iron is attached to high affinity iron binding glycoproteins. ${ }^{5,6}$ Under conditions of iron starvation, many micro-organisms release low-mol. wt compounds termed siderophores, which help them to sequester iron from the environment and from the host. In Escherichia coli, phenolates are synthesised by all strains ${ }^{7,8}$ but it has been reported that only some pathogenic strains elaborate aerobactin. ${ }^{9}$ The nature of the disease produced by a pathogen, i.e., localised or systemic, is influenced by its ability to sequester iron at different body sites. ${ }^{10}$ The importance of this kind of iron availability as a modulator of virulence of micro-organisms has received considerable experimental and speculative attention. ${ }^{11,12}$ The urinary tract provides an environment where iron is a limiting factor. ${ }^{13}$ This study examined how growth in normal urine in vitro, in a situation similar to that in vivo, affected the production of siderophores in $E$. coli. Furthermore, in order to assess its effect on overall virulence of the organism, a model of ascending pyelonephritis in mice was used to compare renal pathogenicity of organisms grown in urine and trypticase soy broth.

\section{Materials and methods}

\section{Bacterial strains}

Seventy urinary isolates of E. coli were examined for their ability to produce hydroxamate (aerobactin)

Received 28 Aug. 1990; accepted 30 Jan. 1991. and 15 producer strains were selected for further study. The organisms were identified according to the methods of Brenner. ${ }^{14}$ The numbers of passages on agar were kept to a minimum before the study was performed. The strains were maintained as nutrientagar stab cultures $\left(\mathrm{pH} \mathrm{7.4)}\right.$ at $4^{\circ} \mathrm{C}$.

\section{Growth media}

Filter-sterilised urine pooled from 3-4 human volunteers and Trypticase Soy Broth (TSB; Difco) were used as the growth media for cultivation of the E. coli strains. All the bacteria were grown overnight at $37^{\circ} \mathrm{C}$ without shaking. The organisms were passaged four times in urine. All the bacterial cultures were harvested by centrifugation. The supernates were collected for siderophore estimations. The bacterial pellets were washed three times with phosphatebuffered saline (PBS; pH 7.3, 0.01 $\mathrm{m}$ ) and then suspended in PBS to give an optical density of 0.5 at $575 \mathrm{~nm}$.

\section{Siderophore estimation}

For estimation of phenolates, the chemical assay of Arnow ${ }^{15}$ was used. The method of Gibson and Magrath ${ }^{16}$ was followed for the estimation of hydroxamates.

\section{Mouse kidney pathogenicity}

The ascending pyelonephritis model of Hagberg et al. ${ }^{17}$ was used but a slight modification, outlined by Sinha et al. ${ }^{18}$ was added. Female LACA strains of Swiss Webster mice, which had sterile urine, were used and these animals were killed on the fifth day after infection. The kidneys were removed aseptically and examined bacteriologically and histopathologi- 
cally. For bacteriological examination, one half of both kidneys was placed in sterile tubes, weighed and homogenised in a Corning glass homogeniser with $1 \mathrm{ml}$ of sterile PBS. Serial dilutions of the homogenate were plated on MacConkey Agar, incubated at $37^{\circ} \mathrm{C}$ for $24 \mathrm{~h}$, and the viable counts were determined from the colony counts.

For histopathological examination, the other half of kidney tissue, preserved in formalin, was dehydrated in an ethanol gradient (70-100\%). The tissue was embedded in paraffin, then sectioned, stained and examined. The severity of infection was graded by the method of Garg et al. ${ }^{19}$

\section{Statistical analysis}

The F-test was used to assess the statistical significance between data from more than two groups and Student's $t$ test was used to assess significant differences between two groups.

\section{Results}

Phenolate production by the 15 strains of $E$. coli after incubation for $24 \mathrm{~h}$ in TSB, and in normal human urine with up to four passages, is shown in table I. All the $E$. coli isolates produced small quantities of phenolates in TSB; these increased significantly $(\mathrm{p}<$ 0.01 ) when the organisms were grown in normal human urine (first passage). There were further increases with subsequent passages in urine. However, increased production in urine after the fourth passage was not significant $(\mathrm{p}>0.05)$.

Hydroxamate production is shown in table II. In TSB, hydroxamate production was very low in most strains tested. However, after they were grown in urine, there were significant increases in production of hydroxamate by all strains $(p<0.01)$. Further increases were observed with additional passages in urine. These increases were seen up to the third passage but were not evident after that.

The results in table III show the renal bacterial counts from mice when organisms had been instilled into the mouse bladder. There was a significant decrease in the numbers of organisms in the kidney when the organisms were initially grown in urine $(\mathrm{p}<$ 0.05 ). After the second passage in urine, there was a significant increase $(\mathrm{p}<0.05)$ in mean renal viable counts compared with organisms used after the first passage. However, this increase was not significant in comparison to organisms grown in TSB $(p>0.05)$. The mean number of $E$. coli present in the kidney increased further only up to the third passage $(\mathrm{p}<$ 0.01 ) and no increase was found between the third and fourth passages $(p>0.05)$.

Histopathological examination of kidneys infected with randomly selected strains showed that, with strains grown in urine (third passage), pathogenicity in the ascending pyelonephritis model was enhanced (figs 1-4). The greatest inflammatory response was observed with strain no. 51 grown in urine, for which the average histopathological score was $11 \cdot 8$. The average score with strains grown in TSB was $2 \cdot 16$, and with organisms grown in urine, at the third passage, $9 \cdot 4$ (table IV).

\section{Discussion}

In this study, we found that all the urinary isolates, when grown in TSB, produced phenolates and that

Table I. Phenolate production by $E$. coli isolates in normal human urine and TSB

\begin{tabular}{|c|c|c|c|c|c|}
\hline \multirow{3}{*}{ Strain no. } & \multicolumn{5}{|c|}{ Optical Density at $515 \mathrm{~nm}$ of strains grown in } \\
\hline & \multirow[b]{2}{*}{$\begin{array}{l}\text { TSB } \\
\text { (a) }\end{array}$} & \multicolumn{4}{|c|}{ urine } \\
\hline & & $\begin{array}{c}\text { 1st } \\
\text { passage } \\
\text { (b) }\end{array}$ & $\begin{array}{l}\text { 2nd } \\
\text { passage } \\
\text { (c) }\end{array}$ & $\begin{array}{c}\text { 3rd } \\
\text { passage } \\
\text { (d) }\end{array}$ & $\begin{array}{c}4 \text { th } \\
\text { passage } \\
\text { (e) }\end{array}$ \\
\hline 1 & 0.092 & $0 \cdot 246$ & $0 \cdot 278$ & 0.323 & 0.327 \\
\hline 2 & $0 \cdot 113$ & $0 \cdot 282$ & 0.291 & 0.412 & 0.419 \\
\hline 3 & 0.056 & 0.262 & 0.283 & 0.307 & 0.299 \\
\hline 6 & 0.069 & 0.310 & 0.319 & $0 \cdot 327$ & 0.345 \\
\hline 8 & 0.089 & 0.373 & 0.413 & 0.456 & 0.457 \\
\hline 11 & 0.082 & 0.263 & 0.299 & $0 \cdot 368$ & $0 \cdot 373$ \\
\hline 13 & 0.073 & 0.300 & 0.322 & 0.354 & 0.342 \\
\hline 22 & 0.081 & 0.296 & 0.305 & 0.316 & $0 \cdot 301$ \\
\hline 23 & $0 \cdot 117$ & 0.421 & 0.452 & 0.492 & 0.481 \\
\hline 25 & 0.087 & 0.425 & 0.449 & 0.485 & 0.483 \\
\hline 42 & $0 \cdot 153$ & $0 \cdot 384$ & 0.411 & 0.443 & 0.439 \\
\hline 49 & 0.071 & 0.526 & 0.578 & 0.638 & 0.637 \\
\hline 51 & 0.082 & 0.233 & $0 \cdot 278$ & 0.314 & $0 \cdot 321$ \\
\hline 5 & 0.072 & $0 \cdot 263$ & 0.292 & 0.338 & 0.334 \\
\hline 9 & 0.091 & $0 \cdot 216$ & $0 \cdot 254$ & 0.298 & 0.289 \\
\hline
\end{tabular}

F-test, $\mathrm{p}<0.05$; Student's $t$ test : $\mathrm{a}$ and $\mathrm{b}, \mathrm{p}<0.01$, a and $\mathrm{c}, \mathrm{p}<0.01$, a and $\mathrm{d},<0.01, \mathrm{~d}$ and $\mathrm{e}, \mathrm{p}>0.05$. 
Table II. Hydroxamate production by $E$. coli isolates in normal human urine and TSB

\begin{tabular}{|c|c|c|c|c|c|}
\hline \multirow[b]{3}{*}{ Strain no. } & \multicolumn{5}{|c|}{ Optical Density at $526 \mathrm{~nm}$ of strains grown in } \\
\hline & \multirow[b]{2}{*}{$\begin{array}{l}\text { TSB } \\
\text { (a) }\end{array}$} & \multicolumn{4}{|c|}{ urine } \\
\hline & & $\begin{array}{c}\text { 1st } \\
\text { passage } \\
\text { (b) }\end{array}$ & $\begin{array}{l}\text { 2nd } \\
\text { passage } \\
\text { (c) }\end{array}$ & $\begin{array}{c}\text { 3rd } \\
\text { passage } \\
\text { (d) }\end{array}$ & $\begin{array}{c}\text { 4th } \\
\text { passage } \\
\text { (e) }\end{array}$ \\
\hline 1 & 0.031 & $0 \cdot 276$ & 0.498 & 0.613 & 0.609 \\
\hline 2 & 0.011 & $0 \cdot 198$ & 0.356 & 0.425 & 0.427 \\
\hline 3 & 0.019 & 0.278 & 0.443 & 0.512 & 0.517 \\
\hline 6 & 0.014 & $0 \cdot 162$ & 0.419 & 0.523 & 0.522 \\
\hline 8 & 0.012 & $0 \cdot 167$ & 0.307 & 0.329 & 0.329 \\
\hline 11 & 0.017 & 0.097 & 0.286 & $0 \cdot 315$ & $0 \cdot 327$ \\
\hline 13 & 0.032 & $0 \cdot 268$ & 0.278 & 0.342 & $0 \cdot 351$ \\
\hline 22 & 0.026 & $0 \cdot 220$ & 0.429 & 0.612 & 0.615 \\
\hline 23 & 0.032 & 0.079 & 0.413 & 0.478 & 0.462 \\
\hline 25 & 0.015 & $0 \cdot 109$ & $0 \cdot 293$ & $0 \cdot 367$ & $0 \cdot 366$ \\
\hline 42 & 0.021 & $0 \cdot 168$ & 0.377 & 0.527 & 0.528 \\
\hline 49 & 0.017 & $0 \cdot 214$ & 0.421 & 0.568 & 0.558 \\
\hline 51 & 0.026 & 0.155 & 0.418 & 0.537 & 0.539 \\
\hline 5 & 0.013 & $0 \cdot 125$ & 0.357 & 0.498 & 0.492 \\
\hline 9 & 0.016 & $0 \cdot 235$ & 0.378 & 0.532 & 0.531 \\
\hline
\end{tabular}

F-test, $\mathrm{p}<0.05$; Student's $t$ test: $\mathrm{a}$ and $\mathrm{b}, \mathrm{p}<0.01$, a and $\mathrm{c}, \mathrm{p}<0.01$, a and $\mathrm{d}, \mathrm{p}<0.01, \mathrm{~d}$ and $\mathrm{e}, \mathrm{p}>0.05$.

Table III. Kidney colonisation in vivo by isolates of $E$. coli grown in normal human urine and TSB

\begin{tabular}{|c|c|c|c|c|c|}
\hline \multirow{3}{*}{ Strain no. } & \multicolumn{5}{|c|}{ Mean number of bacteria $\left(\log _{10} \mathrm{cfu} / \mathrm{g}\right)$ in kidney tissue of strains grown in } \\
\hline & \multirow[b]{2}{*}{$\begin{array}{l}\text { TSB } \\
\text { (a) }\end{array}$} & \multicolumn{4}{|c|}{ urine } \\
\hline & & $\begin{array}{c}\text { 1st } \\
\text { passage } \\
\text { (b) }\end{array}$ & $\begin{array}{l}\text { 2nd } \\
\text { passage } \\
\text { (c) }\end{array}$ & $\begin{array}{c}\text { 3rd } \\
\text { passage } \\
\text { (d) }\end{array}$ & $\begin{array}{c}\text { 4th } \\
\text { passage } \\
\text { (e) }\end{array}$ \\
\hline 1 & 3.63 & 3.01 & $4 \cdot 16$ & 6.46 & 6.49 \\
\hline 2 & $3 \cdot 22$ & 2.95 & 3.72 & 6.01 & 6.02 \\
\hline 3 & 4.40 & 3.51 & 4.50 & 7.51 & 7.62 \\
\hline 6 & $2 \cdot 28$ & $2 \cdot 01$ & 2.52 & 6.24 & $6 \cdot 25$ \\
\hline 8 & $3 \cdot 12$ & 2.42 & 3.02 & $5 \cdot 81$ & $5 \cdot 80$ \\
\hline 11 & 2.96 & 2.06 & 3.41 & $5 \cdot 56$ & 5.45 \\
\hline 13 & $2 \cdot 23$ & 1.56 & 2.95 & 6.63 & 6.62 \\
\hline 22 & $4 \cdot 41$ & $3 \cdot 13$ & 4.71 & 6.31 & 6.42 \\
\hline 23 & $2 \cdot 58$ & 2.02 & 2.96 & 5.88 & 5.85 \\
\hline 25 & $4 \cdot 41$ & 3.82 & 4.91 & $5 \cdot 20$ & $5 \cdot 23$ \\
\hline 42 & 3.78 & $3 \cdot 20$ & 3.98 & 5.56 & 5.58 \\
\hline 49 & $4 \cdot 02$ & 3.43 & 4.32 & 6.84 & 6.86 \\
\hline 51 & 3.57 & 2.97 & 3.98 & 6.52 & 6.95 \\
\hline 5 & 2.53 & $2 \cdot 12$ & $3 \cdot 12$ & $5 \cdot 13$ & 5.01 \\
\hline 9 & $4 \cdot 13$ & $3 \cdot 16$ & 4.53 & $7 \cdot 23$ & $7 \cdot 29$ \\
\hline
\end{tabular}

F-test $; \mathrm{p}<0.05 ;$ Student's $t$ test: a and $\mathrm{b}, \mathrm{p}<0.05$, a and $\mathrm{c}, \mathrm{p}>0.05$, b and $\mathrm{c}, \mathrm{p}<0.05$, a and $\mathrm{d}, \mathrm{p}<0.05$, $c$ and $d, p<0.01, d$ and $e, p>0.05$.

the amount of the phenolates produced increased up to the third passage in urine as a culture medium. Iron-deficient conditions in urine can explain these observations. Mutant strains of E. coli lacking ferric enterochelin esterase activity have been reported to be disadvantaged when grown in iron-deficient medium. ${ }^{20}$ In relation to enterochelin production and virulence of $E$. coli it has been reported that ironbinding catechols are secreted in both synthetic medium and in serum. Furthermore, transferrin and ethylenediamine-di-( $O$-hydroxyphenyl) acetic acid (EDDA) induce catechol production and abolish bacteriostasis in vivo. ${ }^{21}$

Williams and Carbonetti ${ }^{9}$ showed that although aerobactin has markedly lower affinity for iron than enterochelin, it provides a selective advantage for growth of bacteria in iron-limited conditions in body tissues and fluids. Aerobactin is repeatedly re-usable 


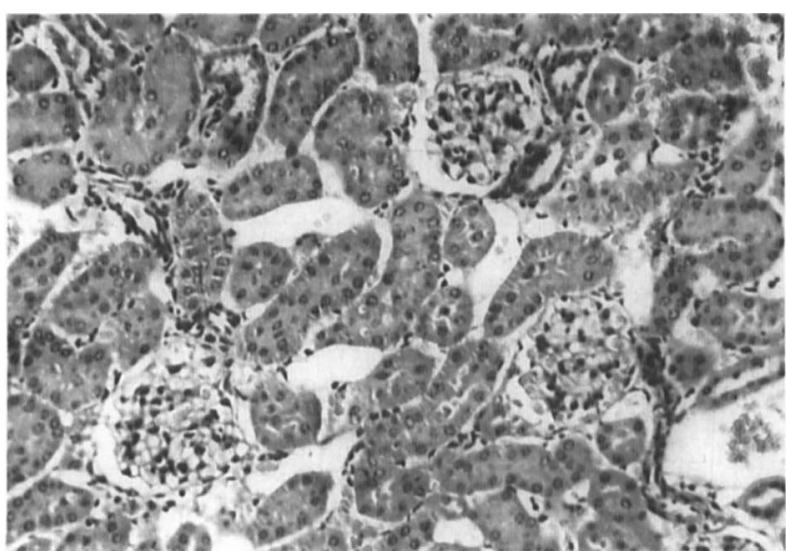

Fig. 1. Photomicrograph showing histological appearance of normal mouse kidney (Severity score, 0 ); haematoxylin and eosin, $\times 100$

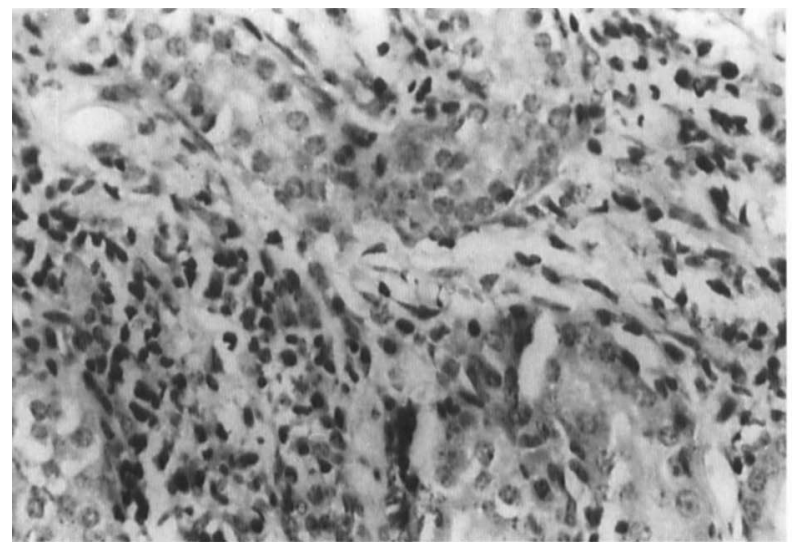

Fig. 3. Photomicrograph showing interstitial infiltrate consisting of polymorphs and lymphocytes (Severity score, 4); haematoxylin and eosin, $\times 200$.

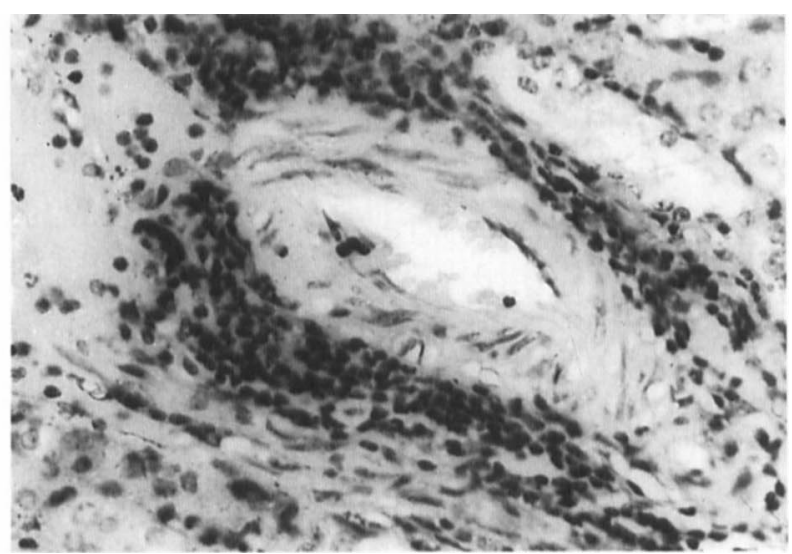

Fig. 2. Photomicrograph showing dense perivascular infiltrate (Severity score, 2); haematoxylin and eosin, $\times 200$

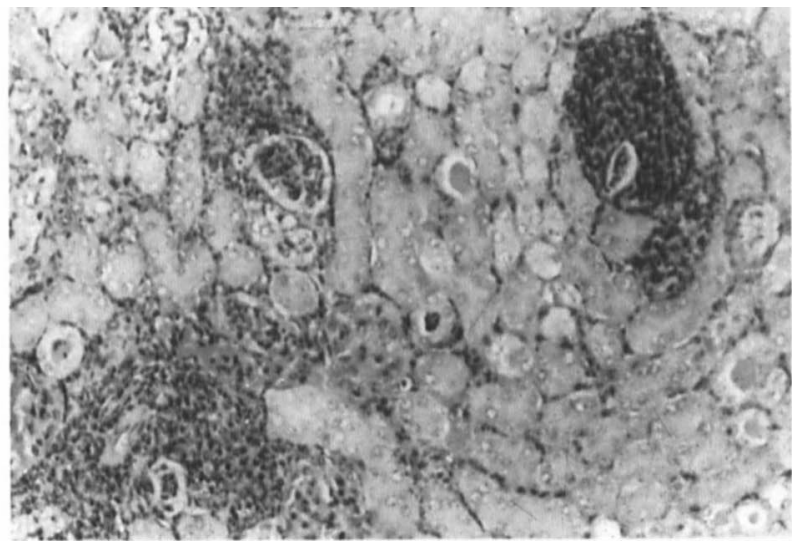

Fig. 4. Photomicrograph showing multiple micro-abscesses in the renal cortex (Severity score, 12); haematoxylin and eosin, $\times 100$.

Table IV. Severity score of pathological lesions in kidneys infected with $E$. coli grown in TSB or urine

\begin{tabular}{c|cc}
\hline \multirow{2}{*}{ Strain no. } & \multicolumn{2}{|c}{ Mean (SD) Severity score with strains grown in } \\
\cline { 2 - 3 } & TSB & urine \\
\hline 3 & $1 \cdot 80(0 \cdot 63)$ & $10 \cdot 80(1 \cdot 35)$ \\
13 & $2 \cdot 00(0 \cdot 82)$ & $7.50(0 \cdot 79)$ \\
25 & $2 \cdot 17(0 \cdot 56)$ & $7 \cdot 80(0 \cdot 95)$ \\
51 & $2 \cdot 68(0.48)$ & $11 \cdot 80(1 \cdot 20)$ \\
\hline
\end{tabular}

For TSB $v s$ urine, $\mathrm{p}<0.01$ (Student's $t$ test).

and has been found to stimulate bacterial growth at extracellular concentrations 500 -fold lower than that of enterochelin. Stuart et al. ${ }^{22}$ reported that the ability for hydroxamate-mediated transport of iron is widely distributed among natural isolates of $E$. coli, but that the distribution of hydroxamate-positive $E$. coli is not random. E. coli isolates from sources where levels of available iron are expected to be low tend to be hydroxamate-positive. Our present observations support the hypothesis that natural iron-limiting conditions, as prevail in urine, enhance the production of hydroxamates. Whether enhanced elaboration of siderophores by organisms grown in urine depend on selection of phenotypic variation has yet to be explored. Bacterial counts in kidneys and observed inflammatory responses further substantiate the view that the overall virulence of organisms grown in urine is enhanced up to the third passage. Urine is a complex product, with variable amounts of uromucoid, T-H proteins and other chemicals. Their precise role, alone or in combination, in the elaboration of siderophores and virulence is currently being investigated further. 


\section{References}

1. Weinberg ED. Iron and infection. Microbiol Rev 1978; 42: 4566.

2. Messenger AJM, Barclay R. Bacteria, iron and pathogenicity. Biochem Ed 1983; 11: 54-63.

3. Weinberg ED. Iron withholding: a defense against infection and neoplasia. Physiol Rev 1984; 64: 65-102.

4. Griffiths E. Iron in biological systems. In Bullin JJ, Griffiths E (eds) Iron and infection: molecular physiological and clinical aspects. Chichester, John Wiley and Sons. 1987: $1-25$.

5. Bullen JJ, Rogers HJ, Griffiths E. Role of iron in bacterial infection. Curr Top Microbiol Immunol 1978; 80: 1-35.

6. Aisen P. The transferrins. In Jacobs A, Worwood $\mathbf{M}$ (eds) Iron in biochemistry and medicine, vol 2. London, Academic Press. 1980: 87-129.

7. Brot $\mathrm{N}$, Goodwin J, Fales $\mathrm{H}$. In vivo and in vitro formation of 2 , 3-dihydroxybenzoylserine by Escherichia coli K-12. Biochem Biophys Res Commun 1966; 25 : 454-461.

8. Griffiths E, Chart H, Stevenson P. High-affinity iron uptake systems and bacterial virulence. In: Roth JA (ed) Virulence mechanisms of bacterial pathogens. Washington, DC, American Society for Microbiology. 1988.

9. Williams PH, Carbonetti HN. Iron, siderophores, and pursuit of virulence: independence of aerobactin and enterochelin iron uptake systems in Escherichia coli. Infect Immun 1986; 51: $942-947$.

10. Payne SM, Finkelstein RA. The critical role of iron in hostbacterial interactions. J Clin Invest 1978; 61 : 1428-1440.

11. Neilands JB. Iron absorption and transport in microorganisms. Annu Rev Nutr 1981; 1: 27-46.

12. Finkelstein RA, Sciortino CV, McIntosh MA. Role of iron in microbe host interactions. Rev Infect Dis 1983; 5: S759S777.
13. Shand GH, Anwar H, Kadurugamuwa J, Brown MRW, Silverman SH, Melling J. In vivo evidence that bacteria in urinary tract infection grow under iron-restricted conditions. Infect Immun 1985; 48: 35-39.

14. Brenner DJ. Enterobacteriaceae. In: Krieg NR, Holt JG (eds) Bergey's Manual of systematic bacteriology, vol 1, Baltimore, Williams and Wilkins. 1984: 408-423.

15. Arnow LE. Colorimetric determination of the components of 3, 4-dihydroxyphenylalaninelyrosine mixtures. J Biol Chem 1937; 118: 531-537.

16. Gibson F, Magrath DI. The isolation and characterization of hydroxamic acid (aerobactin) formed by Aerobacter aerogenes 62-1. Biochim Biophys Acta 1969; 192: 175-184.

17. Hagberg L, Freter R, Hull S, Svanborg-Eden C. Ascending unobstructed urinary tract infection in mice: a model for the study of bacterial attachment. In:Kensch G, Wadström $\mathrm{T}$ (eds) Experimental bacterial and parasitic infections. Proceedings of the Workshop on Experimental Bacterial and Parasitic Infections, June 11-13, 1982. Tammavisk Mansion, Sweden. 1983: 119-124.

18. Sinha N, Harjai K, Sharma S. Ascending pyelonephritis model in Swiss Webster (LACA) mice. Indian J Med Res 1988; 88: $541-544$.

19. Garg UC, Ganguly NK, Sharma S, Chakravarti RN, Bhatnagar RK. Quantitative histopathological method for the evaluation of experimental ascending pyelonephritis. Med Sci Res (Biomedical Technology Section) 1987; 15:367-368.

20. Langman L, Young IG, Frost GE, Rosenberg H, Gibson F. Enterochelin system of iron transport in Escherichia coli: mutations affecting ferric-enterochelin esterase. $J$ Bacteriol 1972 ; 112: 1142-1149.

21. Rogers HJ. Iron-binding catechols and virulence in Escherichia coli. Infect Immun 1973; 7: 445-456.

22. Stuart SJ, Greenwood KT, Luke RKJ. Iron-suppressible production of hydroxamate by Escherichia coli isolates. Infect Immun 1982; 36: 870-875. 